\title{
Efektivitas Biaya Kualitas dalam Rangka Menekan Produk Rusak pada PT. Perkebunan Nusantara XI PG. Redjosarie
}

\section{The Effectiveness of Quality Cost to Suppress Damaged Products at PT. Perkebunan Nusantara XI PG. Redjosarie}

\author{
Intia Puspita Waty Sudibyo ${ }^{1 *}$, Farida Ratna Dewi ${ }^{1}$ \\ 1) Departemen Manajemen, Fakultas Ekonomi dan Manajemen, IPB Kampus Dramaga Bogor 16680
}

\begin{abstract}
Company implements quality cost to prevent and surpress the existence of damaged products. This research is conducted at PT. Perkebunan Nusantara XI Redjosarie Sugar Factory that produces white crystal sugar. Quality costs applied by Redjosarie Sugar Factory consists of prevention cost and appraisal cost. The aim of this study is to identify the condition of damaged products and causatife factors of damaged products, analyze the things that affect the effectiveness of quality cost in order to surpress the damaged products. The result shows the highest percentage of damaged products compared to the total production showing a figure 0,0115 percent and the factors causing the damaged products at Redjosarie Sugar Factory are man factor, machine factor, material factor, method factor and modal factor. While the implementation of cost quality in surpessing damaged products is not effective because the percentage index of quality cost compared to total sales shows a figure above 2,5 percent.
\end{abstract}

Keywords: damaged product, quality cost, white crystal sugar.

\begin{abstract}
ABSTRAK
Penerapan biaya kualitas merupakan salah satu cara perusahaan dalam mencegah dan menekan keberadaan produk rusak. Penelitian ini dilakukan PT. Perkebunan Nusantara XI PG. Redjosarie yang memproduksi gula kristal putih. Biaya kualitas yang diterapkan oleh PG. Redjosarie terdiri dari biaya pencegahan dan biaya penilaian. Tujuan penelitian ini adalah mengidentifikasi jenis-jenis biaya kualitas yang diterapkan, mengidentifikasi kondisi produk rusak dan faktor-faktor penyebab terjadinya produk rusak, serta menganalisa hal-hal yang memengaruhi efektivitas biaya kualitas dalam rangka menekan produk rusak. Hasil menunjukkan persentase tertinggi produk rusak yang dibandingkan dengan jumlah produksi yaitu sebesar 0,0115 persen dan faktor-faktor penyebab terjadinya produk rusak di PG. Redjosarie adalah faktor manusia, faktor mesin, faktor material, faktor bahan baku dan faktor modal. Sementara penerapan biaya kualitas dalam menekan produk rusak dapat dikatakan belum efektif karena indeks persentase perbandingan biaya kualitas dengan total penjualan menunjukkan angka di atas 2,5 persen.
\end{abstract}

Kata kunci: biaya kualitas, gula kristal putih, produk rusak. 


\section{PENDAHULUAN}

Gula merupakan bahan dasar yang digunakan oleh seluruh kalangan masyarakat Indonesia. Berdasarkan Buletin Konsumsi Pangan Kementerian Pertanian (2016) menunjukkan bahwa total konsumsi penggunaan gula tahun 2012-2016 secara berturut-turut adalah 4.933.112 ton, 5.594.497 ton, 5.469.497 ton, 5.957.409 ton dan 6.508.769 ton. Dari data tersebut dapat dilihat bahwa terjadi peningkatan konsumsi penggunaan gula setiap tahunnya. Dengan melihat trend peningkatan kebutuhan gula setiap tahun menyebabkan pabrik gula harus memproduksi sesuai dengan permintaan konsumen dan memerhatikan kualitas gula kristal putih yang diproduksi. Dalam menghasilkan gula kristal putih, PG. Redjosarie memproduksi sesuai dengan Standar Nasional Indonesia (SNI GKP No 3140.3.2010). Jika, gula yang dihasilkan pada proses produksi tidak sesuai dengan standar yang diterapkan dapat dikategorikan sebagai produk rusak. Menurut Bustami dan Nurlela (2006), produk rusak adalah produk yang dihasilkan dalam proses produksi, dimana produk yang dihasilkan tersebut tidak sesuai dengan standar mutu yang ditetapkan, tetapi secara ekonomis produk tersebut dapat diperbaiki dengan mengeluarkan biaya tertentu, tetapi biaya yang dikeluarkan cenderung lebih besar dari nilai jual setelah produk tersebut diperbaiki.

Adapun produk rusak yang dihasilkan PG. Redjosarie adalah gula krikilan dan gula halus. Berdasarkan data jumlah produk rusak yang dihasilkan PG. Redjosarie selama periode masa giling 2012-2016 memperlihatkan bahwa nilai tertinggi pada persentase produk rusak terhadap jumlah produksi ada pada tahun 2012 yaitu sebesar 0,054 persen, sementara nilai terendah persentase produk rusak terhadap jumlah produksi ada pada tahun 2014 yaitu sebesar 0,019 persen. Berdasarkan data mengenai produk rusak yang ada dapat dikatakan bahwa produk rusak yang dihasilkan selama lima periode masa giling masih dalam batas pengendalian. Walaupun jumlah produk rusak yang dihasilkan masih dalam batas pengendalian, namun keberadaan produk rusak tetap menimbulkan kerugian bagi PG. Redjosarie.

Kerugian yang ditimbulkan oleh produk rusak pada tahun 2012 yaitu sebesar Rp 79.438.825,00. Jumlah kerugian tersebut didapatkan dari perkalian jumlah produk rusak tahun 2012 yaitu sebesar 9,4 ton dengan nilai HPP pada tahun tersebut yaitu sebesar Rp 8.450,94/Kg. Kerugian yang ditimbulkan oleh produk rusak menyebabkan setiap perusahaan termasuk PG. Redjosarie berusaha menghindari keberadaan produk rusak. Dalam mengatasi terjadinya produk rusak, manajemen perusahaan menerapkan biaya kualitas. Biaya kualitas adalah biaya yang terjadi atau mungkin akan terjadi karena kualitas yang buruk. Jadi biaya kualitas adalah biaya yang berhubungan dengan penciptaan, pengidentifikasian, perbaikan dan pencegahan kerusakan (Tjiptono \& Diana, 2003).

Terdapat pandangan bahwa biaya kualitas dapat mencegah dan mengurangi keberadaan produk rusak, sehingga penelitian ini bertujuan untuk: 1) Mengidentifikasi jenis-jenis biaya kualitas yang diterapkan oleh PG. Redjosarie selama periode tahun 2012-2016; 2) Mengidentifikasi kondisi produk rusak dan faktor-faktor yang menyebabkan produk rusak pada PG. Redjosarie selama periode tahun 2012-2016; dan 3) Menganalisis hal-hal yang memengaruhi efektivitas biaya kualitas dalam rangka menekan produk rusak pada PG. Redjosarie selama periode tahun 2012-2016.

\section{METODE PENELITIAN}

Keberadaan produk rusak merupakan hal penting yang diperhatikan oleh perusahaan. Dengan adanya produk rusak maka perusahaan tidak mendapatkan laba yang seharusnya didapatkan oleh perusahaan. Selain itu, keberadaan produk rusak dapat membuat perusahaan mengalami kerugian karena produk tidak layak dijual dengan harga yang telah ditetapkan. Untuk memperbaiki produk rusak dapat dilakukan pengerjaan ulang yang menimbulkan biaya tambahan sehingga dapat berpengaruh pada Harga Pokok Penjualan (HPP) suatu produk. Maka dari itu, diperlukan biaya kualitas dalam mencegah dan mengurangi jumlah produk rusak.

Biaya kualitas yang digunakan dalam mencegah dan mengurangi produk rusak adalah biaya pencegahan dan biaya penilaian. Menurut Hansen dan Mowen (2005) biaya pencegahan dan penilaian meningkat berarti menunjukkan jumlah unit poduk rusak menurun dan sebaliknya 
jika biaya pencegahan dan biaya penilaian menurun menunjukkan jumlah unit produk rusak meningkat. Hal ini menunjukkan bahwa biaya pencegahan dan biaya penilaian berpengaruh terhadap produk rusak yang dihasilkan. Biaya pencegahan yang diterapkan oleh PG. Redjosarie antara lain biaya biaya pegendalian hama dan penyakit, biaya pelatihan karyawan, serta biaya perawatan bangunan dan mesin. Sedangkan biaya penilaian meliputi biaya segala upah pengawas pengolahan basah, biaya uji produk dan biaya pembelian peralatan analisa.

Metode pengolahan data yang digunakan adalah dengan metode deskriptif. Selain itu analisis mengenai faktor-faktor yang memengaruhi keberadaan produk rusak menggunakan diagram sebab-akibat. Berikut adalah gambaran kerangka pemikiran penelitian ini:

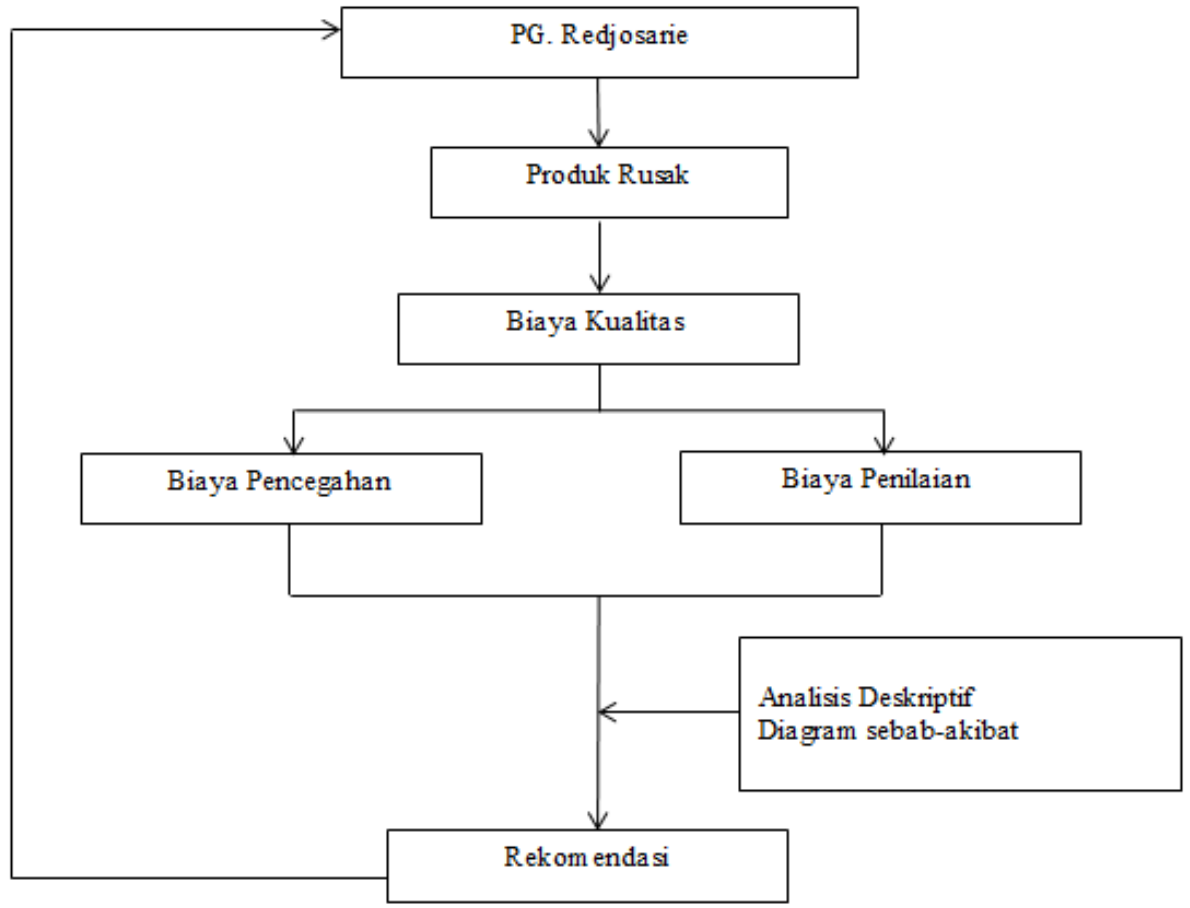

Gambar 1. Kerangka Pemikiran Penelitian

Penelitian ini menggunakan data primer dan data sekunder. Data primer dalam penelitian ini adalah dengan melakukan wawancara langsung dengan pihak PG. Redjosarie untuk memperoleh data yang terkait dengan topik penelitian yakni biaya kualitas dan produk rusak. Sedangkan, data sekunder diperoleh dari laporan biaya perusahaan selama periode 2012-2016. Data yang digunakan dalam penelitian ini mencakup data sekunder yang bersifat kuantitatif dan kualitatif.

\section{HASIL DAN PEMBAHASAN}

\section{Gambaran Umum}

Objek dalam penelitian ini adalah Pabrik Gula Redjosarie yang didirikan oleh pemerintah Hindia Belanda pada tahun 1890 dan awalnya dimiliki oleh pihak Nationale Industrie \& Landbouw Maatschappy (NILM). Pada tanggal 27 Desember 1957 Pabrik Gula Redjosarie diambil alih oleh Pemerintah Republik Indonesia dan pada tahun 1960-1963 Pabrik Gula Redjosarie berstatus Perusahaan Perkebunan Negara (PPN) kesatuan Jawa Timur I Surabaya. Pada tahun 1963-1968 Pabrik Gula berstatus Perusahaan Gula Negara dan dikelola oleh Perusahaan Perkebunan Gula daerah inspeksi wilayah V Surabaya yang bernaung di bawah Departemen Pertanian Republik Indonesia. Pada tahun 1968-1981 Pabrik Gula Redjosarie yang berstatus Perusahaan Negara dan dikelola oleh Direksi Perusahaan Negara Perkebunan XX berkedudukan di Jalan Merak No.1 Surabaya. Pada tanggal 1 Mei 1981 sampai tanggal 13 Februari 1996, Pabrik Gula Redjosarie berstatus Perusahaan Perseroan Terbatas (Persero) dengan Peraturan Pemerintah No. 6 Tahun 1972 dan Peraturan Pemerintah No. 43 Tahun 1974 telah menyatakan "Perusahaan Negara Perkebunan XX" dan disingkat dengan "PT. Perkebunan XX

Jurnal Manajemen dan Organisasi (JMO),

Vol. 10 No. 2 , Agustus 2019, Hal. $102-111$ 
(Persero) Pabrik Gula Redjosarie". Pada tanggal 14 Februari 1996 sampai dengan sekarang berstatus PT. Perkebunan Nusantara XI (Persero) dan bernaung di bawah Departemen Keuangan dan Departemen Pertanian Republik Indonesia.

Produk yang dihasilkan Pabrik Gula Redjosarie adalah gula kristal putih. Adapun proses pengolahan gula kristal putih dari tebu hingga menjadi gula memerlukan waktu pengolahan selama kurang lebih 3 hari. Proses pengolahan gula kristal putih melewati enam stasiun kerja, antara lain: stasiun gilingan, stasiun pemurnian, stasiun penguapan, stasiun masakan, stasiun putaran dan stasiun penyelesaian.

\section{Biaya Kualitas}

Menurut Blocher et al. (2000) biaya kualitas adalah biaya-biaya yang berkaitan dengan pencegahan, pengidentifikasian, perbaikan dan pembetulan produk yang berkualitas rendah dan dengan opportunity cost dari hilangnya waktu produksi dan penjualan sebagai akibat rendahnya kualitas. Jenis biaya kualitas yang digunakan dalam mencegah dan menekan jumlah produk rusak pada PG. Redjosarie adalah biaya pencegahan dan biaya penilaian.

Biaya Pencegahan

Biaya pencegahan merupakan biaya yang dikeluarkan oleh perusahaan dalam mencegah terjadinya kerusakan produk yang dihasilkan. Adapun komponen biaya yang dikeluarkan PG. Redjosarie yang termasuk ke dalam biaya pencegahan, yaitu biaya pegendalian hama \& penyakit, biaya pelatihan karyawan dan biaya perawatan bangunan \& mesin. Biaya pencegahan PG. Redjosarie pada periode 2012-2016 dapat dilihat pada Tabel 1.

Tabel 1. Biaya pencegahan PG. Redjosarie pada periode 2012-2016

\begin{tabular}{|c|c|c|c|c|c|}
\hline \multirow{2}{*}{$\begin{array}{l}\text { Aktivitas } \\
\text { Pencegahan }\end{array}$} & \multicolumn{5}{|c|}{ Biaya Tiap Tahun (Rp) } \\
\hline & 2012 & 2013 & 2014 & 2015 & 2016 \\
\hline $\begin{array}{l}\text { Pengendalian Hama } \\
\text { \& Penyakit }\end{array}$ & $416.203 .000,00$ & $79.089 .000,00$ & $183.329 .000,00$ & 19.994.000,00 & $48.553 .000,00$ \\
\hline Pelatihan Karyawan & $114.992 .000,00$ & $40.580 .000,00$ & $78.367 .000,00$ & 103.056.000,00 & $117.000 .000,00$ \\
\hline $\begin{array}{l}\text { Perawatan Bangunan } \\
\text { dan Mesin }\end{array}$ & 4.733.886.000,00 & $5.216 .931 .000,00$ & 2.147.580.000,00 & 2.520.699.000,00 & $2.370 .130 .000,00$ \\
\hline Total & $5.265 .081 .000,00$ & $5.336 .600 .000,00$ & $2.409 .276 .000,00$ & $2.643 .749 .000,00$ & $2.535 .683 .000,00$ \\
\hline
\end{tabular}

Sumber: Data diolah (2017)

Pengendalian mutu untuk mencegah keberadaan produk rusak yang dilakukan oleh PG. Redjosarie tidak hanya dilakukan pada proses pengolahan, melainkan dilakukan juga pengendalian mutu pada saat on farm atau pada kebun tebu. Pengendalian mutu yang dilakukan pada saat on farm yaitu pencegahan hama dan penyakit dengan cara memberikan herbisida dan trikogama pada tanaman tebu yang menjadi bahan baku dari pembuatan gula kristal putih. Selain melakukan pengendalian mutu pada saat on farm, PG. Redjosarie melakukan pelatihan karyawan dan perawatan mesin dan bangunan.

Pelatihan karyawan yang dilakukan PG. Redjosarie diharapkan menghasilkan karyawan yang memiliki kinerja yang baik. Pada Tabel 1 biaya pelatihan karyawan paling tinggi yaitu pada tahun 2012, 2015 dan 2016 berturut-turut sebesar Rp 114.992.151,00, Rp 103.055.000,00, Rp 117.000.000,00. Hal ini dikarenakan pada tahun tersebut terdapat pelatihan eksternal yang dilaksanakan di luar kota sehingga menimbulkan biaya yang tinggi. Perawatan mesin dan bangunan dilakukan oleh PG. Redjosarie dalam rangka mencegah terjadinya produk rusak. Mesin yang digunakan oleh pabrik gula mempengaruhi gula kristal putih yang dihasilkan pada saat proses produksi. Tabel 1 memperlihatkan bahwa biaya perawatan bangunan dan mesin fluktuatif setiap tahunnya. Tinggi dan rendahnya biaya tiap tahunnya tergantung dengan banyaknya pembelian peralatan dan suku cadang yang dilakukan oleh PG. Redjosarie. Biaya perawatan bangunan dan mesin termasuk biaya yang tinggi dibandingkan dengan komponen biaya-biaya pada biaya pencegahan dikarenakan tingginya harga peralatan dan suku cadang impor.

\section{Biaya Penilaian}

Biaya penilaian merupakan biaya yang dikeluarkan oleh perusahaan untuk menentukan apakah produk yang dihasilkan sesuai dengan standar yang ditetapkan. Biaya penilaian yang dikeluarkan oleh PG. Redjosarie, yaitu biaya upah pengawas pengolahan, biaya uji produk dan 
biaya pembelian peralatan analisa. Biaya penilaian PG. Redjosarie selama pada 2012-2016 ditunjukkan pada Tabel 2.

Tabel 2. Biaya penilaian PG. Redjosarie pada periode 2012-2016

\begin{tabular}{lccccc}
\hline \multirow{2}{*}{ Aktivitas Penilaian } & \multicolumn{5}{c}{ Biaya Tiap Tahun (Rp) } \\
\cline { 2 - 6 } & 2012 & 2013 & 2014 & 2015 & 2016 \\
\hline Uji Produk & $2.200 .000,00$ & $9.350 .000,00$ & $18.040 .000,00$ & $14.670 .000,00$ & $16.000 .000,00$ \\
Upah Pengawas & $30.580 .000,00$ & $36.300 .000,00$ & $36.300 .000,00$ & $38.550 .000,00$ & $42.900 .000,00$ \\
$\begin{array}{l}\text { Pengolahan } \\
\text { Pembelian }\end{array}$ & $334.147 .552,00$ & $134.919 .123,00$ & $448.754 .000,00$ & $148.473 .990,00$ & $176.270 .333,00$ \\
$\begin{array}{l}\text { Peralatan Analisa } \\
\text { Total }\end{array}$ & $366.927 .552,00$ & $180.569 .123,00$ & $503.094 .000,00$ & $201.693 .990,00$ & $235.170 .333,00$ \\
\hline Sumber: Data diolah (2017) & & & &
\end{tabular}

Uji produk gula kristal putih dilakukan internal dan eksternal. Pihak yang melakukan uji produk internal adalah divisi Quality Control (QC). Pengujian hasil produksi gula kristal putih dilakukan setiap empat jam sekali atau dua kali dalam satu shift. Pengujian secara berkala merupakan kontrol yang dilakukan pabrik gula dalam mengendalikan kualitas produk yang dihasilkan. Selain pihak QC, pihak internal yang melakukan penilaian terhadap produk gula kristal putih selama proses produksi adalah bagian pengolahan. Pada bagian pengolahan yang bertindak sebagai pengawas antara lain manajer pengolahan, asisten manajer pengolahan, dokter gula (chemiker) dan mandor. Pada Tabel 2 menunjukkan bahwa terjadi peningkatan biaya upah pengawas pengolahan setiap tahun. Hal ini dikarenakan adanya kenaikan Upah Minimum Regional (UMR) setiap tahun yang mempengaruhi peningkatan biaya upah pengawas pengolahan.

Dalam penilaian kualitas gula kristal putih tidak hanya dipengaruhi oleh pihak QC dan pengolahan sebagai pelaksana, namun peralatan analisa yang digunakan juga memiliki peranan penting untuk menilai apakah produk sesuai dengan mutu atau standar yang ditetapkan atau tidak. Berdasarkan Tabel 5, biaya peralatan analisa paling tinggi ada pada tahun 2012 dan 2014 berturutturut sebesar Rp 334.147.552,00 dan Rp 448.754.000,00. Hal ini disebabkan pada tahun 2012, PG. Redjosarie membeli peralatan analisa baru yaitu sucromat untuk menganalisa kandungan brix, pol, dan rendemen dalam nira. Sedangkan, pada tahun 2014, PG. Redjosarie membeli pH digital untuk mengukur tingkat $\mathrm{pH}$ yang ada pada kandungan nira dan gula. Pembelian peralatan ini menyebabkan meningkatnya pos biaya pembelian peralatan analisa pada tahun tersebut.

\section{Produk Rusak}

Menurut Bustami dan Nurlela (2006) produk rusak adalah produk yang dihasilkan dalam proses produksi, dimana produk yang dihasilkan tersebut tidak sesuai dengan standar mutu yang ditetapkan. Adapun produk rusak yang dihasilkan oleh PG. Redjosarie adalah gula krikilan dan gula halus. Data mengenai produk rusak yang terdiri dari gula krikilan dan gula halus yang dihasilkan oleh PG. Redjoarie selama periode 2012-2016 ditunjukkan pada Tabel 3.

Tabel 3. Jumlah produk rusak periode 2012-2016

\begin{tabular}{|c|c|c|c|c|c|}
\hline \multirow[b]{2}{*}{ Tahun } & \multirow[b]{2}{*}{$\begin{array}{l}\text { Jumlah Produksi } \\
\text { (Ton) }\end{array}$} & \multicolumn{2}{|c|}{ Jumlah Produk Rusak (Ton) } & \multirow[b]{2}{*}{$\begin{array}{l}\text { Total Produk } \\
\text { Rusak (Ton) }\end{array}$} & \multirow{2}{*}{$\begin{array}{l}\text { Persentase Produk } \\
\text { Rusak terhadap } \\
\text { Jumlah Produksi }\end{array}$} \\
\hline & & $\begin{array}{c}\text { Gula } \\
\text { Krikilan }\end{array}$ & Gula Halus & & \\
\hline 2012 & $8.911,30$ & 4,36 & 5,04 & 9,4 & $0,11 \%$ \\
\hline 2013 & $5.846,76$ & 4,4 & 2,3 & 6,7 & $0,12 \%$ \\
\hline 2014 & $8.558,46$ & 2,51 & 1,11 & 3,62 & $0,04 \%$ \\
\hline 2015 & $7.620,70$ & 1,71 & 6,42 & 8,13 & $0,11 \%$ \\
\hline \multirow[t]{2}{*}{2016} & $4.980,50$ & 1,74 & 2,6 & 4,34 & $0,09 \%$ \\
\hline & $35.917,72$ & 14,72 & 17,47 & 32,19 & $0,09 \%$ \\
\hline
\end{tabular}

Sumber: Data diolah (2017)

Berdasarkan Tabel 3 jumlah tertinggi produk rusak ada pada tahun 2012 yaitu sebesar 9,4 ton, sementara untuk jumlah terendah produk rusak ada pada tahun 2014 yaitu sebesar 3,62 ton. Sementara, persentase produk rusak dibandingkan dengan jumlah produksi menunjukkan bahwa nilai persentase tertinggi ada pada tahun 2013 yaitu sebesar 0,0115 persen karena jumlah produksi

Jurnal Manajemen dan Organisasi (JMO), Vol. 10 No. 2 , Agustus 2019, Hal. $102-111$ 
pada tahun 2013 cukup rendah dibandingkan dengan periode masa giling lainnya. Berdasarkan observasi yang telah dilakukan di PG. Redjosarie, terdapat beberapa faktor yang menjadi penyebab terjadinya produk rusak. Untuk menganalisa faktor-faktor yang mempengaruhi terjadinya produk rusak digunakan alat analisa yaitu diagram sebab-akibat (diagram fishbone).

\section{Analisis Faktor Penyebab Produk Rusak dengan Diagram Sebab-Akibat}

Diagram sebab-akibat merupakan diagram yang menunjukkan hubungan antara sebab dan akibat. Faktor-faktor yang mengakibatkan terjadinya produk rusak di PG. Redjosarie dibagi menjadi lima faktor antara lain, faktor manusia, faktor mesin, faktor material, faktor modal dan faktor metode. Penjabaran faktor-faktor penyebab kerusakan gula kristal putih pada PG. Redjosarie adalah sebagai berikut:

1. Faktor Mesin

Hampir seluruh mesin yang digunakan PG. Redjosarie dalam mengolah gula kristal putih adalah mesin dan peralatan yang ada sejak tahun 1890. Mesin yang tergolong cukup tua tersebut mengakibatkan terjadinya kerusakan mesin dan peralatan yang tidak dapat dihindari. Kerusakan mesin menyebabkan proses pengolahan gula kristal putih yang terganggu sehingga terjadi peningkatan pada jam berhenti giling. Selain itu, ketersediaan peralatan seperti pompa dan vacuum yang seringkali terganggu dikarenakan uap yang digunakan sebagai power turun. Penurunan pada power disebabkan oleh tekanan ketel rendah. Ketel digunakan untuk membangkitkan tenaga listrik, sehingga jika ketel mengalami kerusakan maka akan mengakibatkan kerusakan produk.

Solusi yang dapat diimplementasikan oleh PG. Redjosarie dalam mengatasi masalah mesin dan peralatan yang digunakan dalam pengolahan gula kristal putih adalah dengan melakukan perawatan preventif dan perawatan korektif. Perawatan preventif dapat dilakukan pada saat Luar Masa Giling (LMG). Implementasi perawatan preventif diharapkan dapat mengurangi frekuensi terjadinya kerusakan mesin dan peralatan pada periode Dalam Masa Giling (DMG). Akan tetapi, perawatan preventif juga harus dilakukan pada periode DMG dengan cara mengecek peralatan yang akan digunakan saat mengolah gula kristal putih. Sedangkan, perawatan korektif dilakukan ketika ada mesin dan peralatan yang mengalami kerusakan. Perawatan korektif yang dilakukan PG. Redjosarie seperti perbaikan ketel yang mengalami tekanan rendah. Perbaikan tersebut harus segera dilakukan agar tidak menganggu proses pengolahan gula kristal putih dan menyebabkan kerusakan produk.

2. Faktor Manusia

Adapun, tenaga kerja yang direkrut pada periode DMG merupakan tenaga kerja yang berasal dari background pekerjaan yang berbeda-beda, sehingga skill mengenai proses pengolahan gula yang dimiilki oleh karyawan tersebut tergolong rendah. Selain itu, tenaga kerrja yang kurang cermat dalam mengolah gula kristal putih merupakan salah satu human error yang tidak dapat dihindari. Kurang cermat dalam melakukan kegiatan produksi yang berarti tenaga kerja tidak bekerja mengikuti SOP yang berlaku di PG. Redjosarie. Hal tersebut dapat memengaruhi kualitas gula kristal putih yang dihasilkan serta dapat menyebabkan terjadinya kerusakan produk gula kristal putih. Solusi yang dapat dilakukan oleh PG. Redjosarie dalam mengatasi hal yang berkaitan dengan faktor manusia adalah dengan melakukan inhouse training dan peningkatan pengawasan dalam proses pengolahan gula kristal putih.

3. Faktor Material

Permasalahan faktor material yang ada di PG. Redjosarie antara lain tebu terbakar, tebu layu dan kualitas tebu tidak sesuai. Penyebab terjadinya tebu terbakar adalah kesengajaan pemilik lahan untuk membakar tebu dengan tujuan untuk mengurangi kotoran yang ada pada tanaman tebu. Sedangkan, tebu layu disebabkan oleh kelebihan bahan baku (over stock) karena tanaman tebu yang dikirim oleh petani tidak sesuai dengan jatah yang ditetapkan sehingga menyebabkan terjadinya penimbunan bahan baku tanaman tebu di emplacement. Selain tebu yang layu, kualitas tebu yang tidak sesuai adalah permasalahan yang disebabkan karena 
sebagian besar bahan baku yang didapatkan PG. Redjosarie berasal dari kebun milik petani sehingga pengawasan kualitas sulit dilakukan.

Solusi yang dapat diterapkan dalam mengatasi masalah tebu terbakar adalah melakukan pengurangan jatah tebang kepada para petani yang mengirim tebu terbakar ke PG. Redjosarie dan mengolah langsung tebu yang terbakar. Untuk tebu layu, solusi yang dapat dilakukan oleh PG. Redjosarie adalah dengan pemberian ZPI, susu kapur serta membatasi jumlah tebu yang masuk. Sedangkan, solusi untuk tebu yang tidak sesuai dengan kualitas yang diterapkan adalah dengan peningkatan pengawasan pada budidaya tebu sehingga dapat menghasilkan tebu yang sesuai dengan kualitas.

4. Faktor Metode

Metode manual yang diterapkan PG. Redjosarie dikarenakan sebgaian besar mesin dan peralatan yang digunakan tergolong tua. Mesin dan peralatan yang tergolong tua tersebut mengakibatkan keakuratan hasil analisis kurang maksimal sehingga kualitas gula kristal putih yang diolah terkadang tidak sesuai dengan standar yang diterapkan. Masalah yang sering terjadi di lapangan terkait metode manual adalah penumpukan tebu dikarenakan turunnya tekanan uap yang digunakan untuk membangkitkan power mesin penggilingan dan bibitan yang tidak sesuai. Solusi yang dapat diterapkan oleh PG. Redjosarie dalam mengatasi masalah yang berkaitan dengan faktor metode adalah dengan melakukan modernisasi mesin dan peralatan secara bertahap, melakukan screening jika terdapat kebocoran dan pengawasan skema masak.

5. Faktor Modal

PG. Redjosarie membutuhkan modal cukup besar untuk melakukan modernisasi mesin dan peralatan. Tujuan dari modernisasi mesin dan peralatan tersebut adalah untuk mengubah mesin dan peralatan yang masih menggunakan metode manual menjadi mesin dan peralatan yang berbasis komputerisasi. Dengan mengubah mesin dan peralatan yang berbasis komputerisasi maka dapat meningkatkan kapasitas giling PG. Redjosarie serta keuntungan dari penjualan gula kristal putih PG. Redjosarie. Akan tetapi permasalahan dari modal adalah adanya kebijakan pemerintah dalam menginvestasikan modal kepada PG. Redjosarie sebagai pabrik gula yang beroperasi di bawah naungan PTPN. Adapun solusi dari permasalahan mengenai kebijakan pemerintah tersebut adalah dengan menerapkan Total Quality Management (TQM) dimana perusahaan memiliki sistem untuk mengidentifikasikan masalah kualitas, mengembangkan solusi, dan menetapkan tujuan perbaikan kualitas.

\section{Analisis Persentase Biaya Kualitas Terhadap Penjualan}

Suatu perusahaan dengan program pengelolaan kualitas yang berjalan baik, biaya kualitas tidak lebih besar dari 2,5 persen dari penjualan. Setiap perusahaan dapat menyusun anggaran untuk menentukan besarnya standar biaya kualitas setiap elemen secara individual sehingga biaya kualitas total yang dianggarkan tidak lebih dari 2,5 persen dari penjualan. Berikut data mengenai persentase biaya kualitas terhadap penjualan PG. Redjosarie selama periode masa giling 20122016 yang dapat dilihat pada Tabel 4.

Tabel 4. Persentase biaya kualitas terhadap penjualan PG. Redjosarie

\begin{tabular}{|c|c|c|c|c|c|}
\hline \multirow[b]{2}{*}{ Tahun } & \multicolumn{2}{|c|}{ Biaya Kualitas (Rp) } & \multirow[b]{2}{*}{$\begin{array}{c}\text { Total Biaya } \\
\text { Kualitas (Rp) }\end{array}$} & \multirow[b]{2}{*}{$\begin{array}{c}\text { Total Biaya } \\
\text { Penjualan (Rp) }\end{array}$} & \multirow{2}{*}{$\begin{array}{c}\text { Persentase } \\
\text { Biaya Kualitas } \\
\text { Terhadap } \\
\text { Penjualan } \\
\end{array}$} \\
\hline & $\begin{array}{c}\text { Biaya } \\
\text { Pencegahan }\end{array}$ & $\begin{array}{c}\text { Biaya } \\
\text { Penilaian }\end{array}$ & & & \\
\hline 2012 & $5.265 .081 .000,00$ & $366.927 .552,00$ & $5.632 .008 .552,00$ & $73.170 .684 .300,00$ & $7,70 \%$ \\
\hline 2013 & $5.336 .600 .000,00$ & $180.569 .123,00$ & $5.517 .169 .123,00$ & $52.790 .396 .040,00$ & $10,45 \%$ \\
\hline 2014 & $2.409 .276 .000,00$ & $503.094 .000,00$ & $2.912 .370 .000,00$ & $61.620 .912 .000,00$ & $4,73 \%$ \\
\hline 2015 & $2.643 .749 .000,00$ & $201.693 .990,00$ & 2.845.442.990,00 & $60.203 .530 .000,00$ & $4,73 \%$ \\
\hline 2016 & $2.535 .683 .000,00$ & $235.170 .333,00$ & $2.770 .853 .333,00$ & $50.158 .615 .500,00$ & $5,52 \%$ \\
\hline
\end{tabular}

Sumber: Data diolah (2017)

Pada Tabel 4 diketahui bahwa persentase biaya kualitas terhadap penjualan tertinggi ada pada tahun 2013 yaitu sebesar 10,45 persen, sedangkan persentase terendah dari biaya kualitas

Jurnal Manajemen dan Organisasi (JMO), Vol. 10 No. 2 , Agustus 2019, 
terhadap penjualan ada pada tahun 2014 dan 2015 yaitu sebesar 4,73 persen. Akan tetapi, berdasarkan data yang terdapat pada Tabel 9 dapat dikatakan bahwa biaya kualitas yang telah diterapkan selama masa giling 2012-2016 masih belum optimal dikarenakan persentase yang didapatkan lebih besar dari 2,5 persen. Salah satu penyebab penerapan biaya kualitas PG. Redjosarie yang kurang optimal adalah biaya-biaya yang termasuk ke dalam biaya kualitas belum dikelompokkan secara terpisah dan masuk ke dalam biaya produksi. Hal tersebut mengakibatkan PG. Redjosarie tidak dapat memberikan kontrol dan pengendalian terhadap biaya-biaya yang dikategorikan sebagai biaya kualitas. Sehingga PG. Redjosarie tidak mengetahui besarnya biaya kualitas yang telah dikeluarkan.

\section{Analisis Persentase Biaya Kualitas terhadap Harga Pokok Penjualan}

Menurut Garspersz (2000) jika nilai presentase biaya kualitas total terhadap nilai harga pokok penjualan semakin rendah maka menunjukkan program perbaikan kualitas yang semakin baik atau dengan kata lain penerapan biaya kualitas dapat dikatakan efektif. Persentase biaya kualitas PG. Redjosarie terhadap HPP ditunjukkan pada Tabel 5.

Tabel 5. Persentase biaya kualitas terhadap HPP

\begin{tabular}{cccccc}
\hline \multirow{2}{*}{ Tahun } & \multicolumn{2}{c}{ Biaya Kualitas (Rp) } & Total Biaya & Harga Pokok & Persentase Biaya \\
\cline { 2 - 3 } & $\begin{array}{c}\text { Biaya } \\
\text { Pencegahan }\end{array}$ & $\begin{array}{c}\text { Biaya } \\
\text { Penilaian }\end{array}$ & Kualitas (Rp) & $\begin{array}{c}\text { Kualitas Terhadap } \\
\text { HPP }\end{array}$ \\
\hline 2012 & $5.265 .081 .000,00$ & $366.927 .552,00$ & $5.632 .008 .552,00$ & $75.308 .850 .782,00$ & $7,48 \%$ \\
2013 & $5.336 .600 .000,00$ & $180.569 .123,00$ & $5.517 .169 .123,00$ & $84.050 .989 .545,00$ & $6,56 \%$ \\
2014 & $2.409 .276 .000,00$ & $503.094 .000,00$ & $2.912 .370 .000,00$ & $76.816 .202 .987,00$ & $3,79 \%$ \\
2015 & $2.643 .749 .000,00$ & $201.693 .990,00$ & $2.845 .442 .990,00$ & $61.650 .335 .588,00$ & $4,62 \%$ \\
2016 & $2.535 .683 .000,00$ & $235.170 .333,00$ & $2.770 .853 .333,00$ & $51.097 .848 .457,00$ & $5,42 \%$ \\
\hline
\end{tabular}

Pada Tabel 5 dapat diketahui bahwa nilai HPP tertinggi ada pada tahun 2013 yaitu sebesar Rp 84.050.989.545,00, sedangkan nilai HPP terendah ada pada tahun 2016 yaitu sebesar Rp 51.097.848.457,00. Selain nilai HPP, pada Tabel 5 menunjukkan persentase biaya kualitas terhadap HPP untuk mengetahui pengendalian kualitas yang terjadi pada PG. Redjosarie. Berdasarkan hasil persentase biaya kualitas terhadap HPP diketahui bahwa dari tahun 2012 menunjukkan angka tertinggi yaitu sebesar 7,48 persen yang berarti program pengendalian mutu dapat dikatakan buruk. Sementara, persentase biaya kualitas terhadap HPP pada tahun 2014 menunjukkan angka terendah yaitu sebesar 3,79 persen yang berarti pengendalian kualitas pada tahun tersebut dapat dikatakan baik. Pada tahun 2013 nilai HPP menunjukkan angka tertinggi dikarenakan pada tahun tersebut mesin mengalami kerusakan dalam waktu yang lama tersebut sehingga menyebabkan biaya produksi yang semakin tinggi namun produksi tidak sesuai.

\section{Analisis Perbandingan Biaya Kualitas terhadap Kerugian yang Disebabkan oleh Produk Rusak}

Dalam proses produksi, keberadaan produk rusak sangat dihindari. Hal ini dikarenakan semakin banyaknya produk rusak yang dihasilkan maka kerugian yang diperoleh akan semakin tinggi. Salah satu cara perusahaan dalam mengatasi terjadinya produk rusak adalah dengan menerapkan biaya kualitas. Biaya kualitas yang diterapkan oleh PG. Redjosarie terdiri dari biaya pencegahan dan biaya penilaian. Sesuai dengan teori yang dikemukanan oleh Hansen dan Mowen (2005) jika biaya pencegahan dan biaya penilaian meningkat yang berarti menujukkan jumlah unit produk rusak menurun dan sebaliknya jika biaya pencegahan dan biaya penilaian menurun menujukkan jumlah unit produk rusak meningkat. Untuk mengetahui efektivitas biaya kualitas terhadap kerugian yang disebabkan oleh produk rusak dapat dilihat pada Tabel 6 . 
Tabel 6. Efektivitas biaya kualitas terhadap kerugian yang disebabkan oleh produk rusak

\begin{tabular}{ccccccc}
\hline \multirow{2}{*}{ Tahun } & $\begin{array}{c}\text { Jumlah } \\
\text { Total Biaya } \\
\text { Kualitas (Rp) }\end{array}$ & $\begin{array}{c}\text { Produksi Gula } \\
\text { Milik PG. } \\
\text { Redjosarie } \\
(\mathrm{Kg})\end{array}$ & $\begin{array}{c}\text { Total } \\
\text { Produk } \\
\text { Rusak } \\
(\mathrm{Kg})\end{array}$ & $\begin{array}{c}\text { Persentase } \\
\text { Produk Rusak } \\
\text { Terhadap } \\
\text { Jumlah Produksi } \\
\text { Gula Milik PG }\end{array}$ & $\begin{array}{c}\text { HPP per } \\
\text { Kg (Rp) }\end{array}$ & $\begin{array}{c}\text { Total } \\
\text { Kerugian } \\
(\mathrm{Rp})\end{array}$ \\
\hline 2012 & $5.632 .008 .552,00$ & 8.911 .300 & 9.400 & $0,11 \%$ & $8.450,939$ & $79.438 .825,00$ \\
2013 & $5.517 .169 .123,00$ & 5.846 .760 & 6.700 & $0,12 \%$ & $14.375,652$ & $96.316 .871,00$ \\
2014 & $2.912 .370 .000,00$ & 8.558 .460 & 3.620 & $0,04 \%$ & $8.975,47$ & $32.491 .202,00$ \\
2015 & $2.845 .442 .990,00$ & 7.620 .700 & 8.130 & $0,11 \%$ & $8.089,852$ & $65.770 .497,00$ \\
2016 & $2.770 .853 .333,00$ & 4.980 .500 & 4.340 & $0,09 \%$ & $10.259,582$ & $44.526 .586,00$ \\
\hline
\end{tabular}

Sumber: Data diolah (2017)

Berdasarkan Tabel 6 diketahui bahwa biaya kualitas tertinggi yang diterapkan oleh PG. Redjosarie ada pada tahun 2012 yaitu sebesar Rp 5.632.008.552,00 dengan total kerugian yang diderita pada tahun tersebut sebesar Rp 79.438.825,00. Sementara penerapan biaya kualitas terendah ada pada tahun 2016 adalah sebesar Rp 2.770.853.333,00 dengan total kerugian yang diperoleh yaitu sebesar Rp 44.526.586,00. Dari data tersebut dapat dianalisa bahwa penerapan biaya kualitas PG. Redjosarie masih belum efektif dimana pada tahun 2012 saat biaya kualitas yang dikeluarkan PG. Redjosarie menunjukkan jumlah tertinggi, total kerugian yang diperoleh pada tahun tersebut juga cukup tinggi. Sebaliknya pada tahun 2016 saat jumlah biaya kualitas yang diterapkan menunjukkan angka terendah, kerugian yang diperoleh PG. Redjosarie pada tahun tersebut cukup rendah. Data pada Tabel 6 dapat dilihat bahwa keberadaan produk rusak akan berdampak pada total kerugian yang didapat oleh PG. Redjosarie. Semakin tinggi produk rusak yang dihasilkan maka total kerugian yang didapatkan akan semakin tinggi.

\section{Implikasi Manajerial}

Berdasarkan hasil penelitian, pada persentase biaya kualitas terhadap penjualan memperlihatkan bahwa penerapan biaya kualitas PG. Redjosarie pada periode masa giling 20122016 belum optimal karena indeks persentase dari perbandingan produk rusak dengan penjualan lebih dari 2,5 persen. Penerapan biaya kualitas yang belum optimal dikarenakan biaya kualitas tidak dikelompokkan tersendiri dan dihitung ke dalam biaya produksi. Hal ini menyebabkan PG. Redjosarie tidak dapat mengontrol biaya kualitas sehingga tidak mengetahui besarnya biaya kualitas yang diterapkan serta dampaknya bagi produk rusak.

Sementara indeks persentase dari perbandingan produk rusak dengan Harga Pokok Penjualan (HPP) menunjukkan bahwa program kualitas terendah ada pada tahun 2012 dengan persentase sebesar biaya kualitas terhadap HPP diketahui bahwa dari tahun 2012 menunjukkan angka tertinggi yaitu sebesar 7,48 persen yang berarti program pengendalian mutu dapat dikatakan buruk. Hal ini disebabkan jumlah produk rusak yang dihasilkan pada tahun tersebut sebesar 9,4 ton dimana merupakan jumlah tertinggi jika dibandingkan dengan tahun-tahun berikutnya. Sementara, persentase biaya kualitas terhadap HPP pada tahun 2014 menunjukkan angka terendah yaitu sebesar 3,79 persen yang berarti pengendalian kualitas pada tahun tersebut dapat dikatakan baik dimana jumlah produk rusak yang dihasilkan sebesar 3.620 ton yaitu merupakan jumlah produk rusak terendah dalam lima periode masa giling 2012-2016.

Analisa perbandingan biaya kualitas terhadap total kerugian yang disebabkan oleh produk rusak dilakukan untuk mengetahui efektivitas biaya kualitas dalam menekan keberadaan produk rusak pada PG. Redjosarie. Berdasarkan hasil analisa yang dilakukan menunjukkan bahwa pada tahun 2012 penerapan biaya kualitas tertinggi yang diterapkan oleh PG. Redjosarie yaitu sebesar $\mathrm{Rp}$ 5.632.008.552,00 dengan total kerugian yang diperoleh pada tahun tersebut sebesar Rp 79.438.825,00. Hal ini menujukkan bahwa penerapan biaya kualitas yang diterapkan belum efektif dimana produk rusak yang dihasilkan pada tahun tersebut cukup tinggi karena dengan penerapan biaya kualitas yang efektif dapat mencegah dan menekan jumlah produk rusak yang terjadi. 
Berdasarkan hasil observasi yang dilakukan di PG. Redjosarie diketahui bahwa terdapat lima yang berdampak langsung pada keberadaan produk rusak selain penerapan biaya kualitas. Lima faktor yang berdampak langsung pada keberadaan produk rusak antara lain, faktor manusia, faktor mesin, faktor material, faktor metode dan faktor modal. Solusi pada permasalahan kelima faktor ini adalah dengan menerapkan Total Quality Management (TQM) untuk meningkatkan kualitas produk gula kristal putih yang dihasilkan. Menurut Nasution (2005) TQM adalah perpaduan semua fungsi manajemen, semua bagian dari perusahaan dan semua orang ke dalan falsafah holistik yang dibangun berdasarkan konsep kualitas, teamwork, produktivitas dan kepuasan konsumen.

\section{KESIMPULAN}

Berdasarkan hasil penelitian mengenai efektivitas biaya kualitas dalam menekan produk rusak pada PG. Redjosarie didapatkan bahwa jenis biaya kualitas yang diterapkan PG. Redjosarie adalah biaya pencegahan dan biaya penilaian. Hasil penelitian produk rusak pada PG. Redjosarie menunjukkan produk rusak yang dihasilkan adalah gula krikilan dan gula halus. Persentase tertinggi jumlah produk rusak yang dibandingkan dengan jumlah produksi ada pada tahun 2013 yaitu sebesar 0,0115 persen. Faktor penyebab produk rusak antara lain, faktor manusia, faktor mesin, faktor metode, faktor modal dan faktor material. Adapun, penerapan biaya kualitas dalam menekan produk rusak selama periode masa giling 2012-2016 di PG. Redjosarie dapat dikatakan belum efektif karena indeks persentase perbandingan biaya kualitas dengan total penjualan menunjukkan angka di atas 2,5 persen.

\section{DAFTAR PUSTAKA}

Blocher, J., Edward, K. H., Chen, T. W., \& Lin. (2000). Manajemen Biaya. Jakarta: Salemba Empat.

[BSN] Badan Standarisasi Nasional. (2011). Gula Kristal - Bagian 2: Rafinasi (Refined Sugar) [Internet]. [diakses pada 14 Juni 2017]. Tersedia pada: http://www.bsn.go.id.

Bustami, B., \& Nurlela. (2006). Akuntansi Biaya. Yogyakarta: Graha Ilmu.

Garspersz, V. (2000). Total Quality Management. Jakarta: PT. Gramedia Pustaka Utama.

Hansen, D., \& Mowen, M. (2005). Akuntansi Manajemen Edisi 7. Jakarta: Salemba Empat.

[KEMENTAN] Kementrian Pertanian Indonesia. 2016. Buletin Konsumsi Pangan. Pusat Data dan Sistem Informasi Pertanian Sekretariat Jenderal Kementrian Pertanian Tahun 2016, vol 7, No 1.

Nasution, M. N. (2005). Manajemen Mutu Terpadu (Total Quality Management). Bogor: Ghalia Indonesia.

Tjiptono, F., \& Diana, A. (2003). Total Quality Management. Yogyakarta: Andi. 